\title{
Cost-benefit analysis of a projected national human papilloma virus vaccination programme in Lebanon
}

Sarah Bahr, ${ }^{1}$ Rania Bzieh, ${ }^{1}$ Ghinwa Y. El Hayek ${ }^{1}$ and Salim Adib ${ }^{1}$

${ }^{1}$ Department of Epidemiology and Population Health, Faculty of Health Sciences, American University of Beirut, Beirut, Lebanon (Correspondence to Ghinwa El Hayek: gyeo1@mail.aub.edu).

\begin{abstract}
Background: The adoption of a population-based human papilloma virus (HPV) vaccination programme is debated in Lebanon on epidemiological, sociocultural, logistical and economic grounds.

Aims: This cost-benefit analysis contributes to generating quantitative evidence necessary for a decision regarding costs through locally available data.

Methods: The 2 sides of the cost-benefit analysis equation are: estimation of the cost of HPV vaccination campaigns targeting 11 year-old girls, using the cheapest vaccine in 2016 and estimation of the management cost for treatment of a yearly average case-load for cervical cancer.

Results: A Cervarix ${ }^{\circledast}$ only campaign would cost US\$ 5407790 to vaccinate 38083 11-year-old girls. The estimated cost of managing a mean annual mixed case-load of 100 incident cervical cancer cases would cost US\$1 1591336 . The nearest break-even point may occur 5 years after this current analysis.

Conclusion: This cost-benefit analysis using limited available data indicates that massive HPV vaccination would not be cost-beneficial under the circumstances existing in 2016. Nevertheless, some indications point to the need for a re-assessment around 2020. This finding will inform public health decision-makers in Lebanon and similar neighbouring countries.

Keywords: HPV vaccination, cost benefit analysis, cervical cancer, Lebanon

Citation: Bahr S; Bzieh R; El Hayek G; Adib S. Cost-benefit analysis of a projected national human papilloma virus vaccination programme in Lebanon. East Mediterr Health J. 2019;25(10):715-721. https://doi.org/10.26719/2019.25.10.715

Received: 05/06/17; accepted: 27/12/17

Copyright (c) World Health Organization (WHO) 2019. Some rights reserved. This work is available under the CC BY-NC-SA 3.o IGO license https:// creativecommons.org/licenses/by-nc-sa/3.o/igo
\end{abstract}

\section{Introduction}

Human papilloma virus (HPV) is transmitted by direct contact, through oral, vaginal or anal sex $(1,2)$. In the Middle East, HPV prevalence in women has varied from $25 \%$ in women with normal cytology up to $98 \%$ in those with genital warts or pre-invasive and invasive lesions (3). In Lebanon, recent HPV infection prevalence estimates are lacking. The latest study conducted in 2001 among 1026 Lebanese women found an extremely low prevalence of $4.9 \%$ (4).

The evidence linking HPV to cervical cancer is extensive. Globally, HPV16 and HPV18 are the most common strains detected in cervical cancer, accounting for $50 \%$ and $20 \%$ respectively (5). In 2 original studies conducted by Finan el al. on small samples of cancerfree Lebanese women with HPV, $78 \%$ and $64 \%$ were found to have HPV 16 in 2000 and 2001 respectively (6,7). Fewer had HPV 18, while other serotypes were almost inexistent.

Cervical cancer is largely preventable, either through primary prevention by HPV vaccination or through secondary prevention by PAP smear screening or direct visualization of pre-cancer lesions (8). Three vaccines are currently licensed by the Ministry of Public Health (9). Bivalent Cervarix $^{\circledast}$ provides protection against the 2 most serious types of HPV strains. Quadrivalent Gardasi ${ }^{\oplus}$ protects against HPV 16 and 18 , as well as HPV6 and HPV-11 (more frequently associated with genital warts). Nonavalent Gardasil ${ }^{\oplus}$ was licensed in Lebanon in 2016 but is still not widely prescribed. The efficacy of HPV vaccines against infections in young women can reach $100 \%$, provided vaccination is administered before initiation of potential sexual exposure (10-13). Population-based studies, with almost 10 years of followup, have shown that vaccines can substantially reduce the risk for cervical cancer in vaccinated women (14). In 2016, the Centers for Disease Control and Prevention started recommending 2 doses of either the bivalent or the quadrivalent vaccine, 6 months apart, for girls aged 11-12 years, while older women (15-26 years old) would require 3 doses (15). Since most previous findings indicate the predominance of HPV-16 and 18 in the Lebanese population, the use of the quadrivalent or nonavalent vaccines would not have a significant protective added value compared to the bivalent vaccine.

The historical dynamics of cervical cancer in Lebanon suggest that the disease has a low endemicity. In the 1960s, Abou-Daoud estimated the incidence at 19.7/100 000 (16). It has been decreasing since then, and the latest update from the National Cancer Registry reported it at 5.3/100 000 in 2010, with a total cancer incidence for 
women at 264.8/100 000 (17). The number of new cases was consistently low for the years 2005-2010: 82, 76, 100, 106, 75 and 102 cases respectively. The median age at diagnosis varies between 53 and 55 years (17-22).

WHO recommends including HPV vaccination in national immunization programmes. However, the adoption of HPV vaccination for the prevention of cervical cancer in national policies is largely dependent on the epidemiology and financial situation of each country. Higher-income countries may be able to afford the cost of vaccination, regardless of the epidemiological magnitude of cervical cancer incidence, especially if HPV exposure is high $(23,24)$. Lower-income countries may also find it beneficial when the prevalence of HPV infection or the cervical cancer caseload are high (25).

There are currently no national guidelines in Lebanon regarding HPV vaccination. The opportunity of starting a massive HPV vaccination programme is debated on epidemiological, sociocultural, logistical and most importantly economic grounds (3). The debate has not been informed so far by any quantitative evidence regarding costs and outcomes. This costbenefit analysis contributes to generating the evidence necessary for a decision in Lebanon through locally available data.

\section{Methods}

\section{Sources and types of data}

Various sources of data were mined to obtain the variables needed for the 2 sides of the cost-benefit analysis equation: cost of vaccination vs cervical cancer management. Other types of cancers associated with HPV infection: anal, vaginal, vulvar and head and neck cancers were disregarded because of their extreme rarity in Lebanon. All costs were based on standard protocols currently in place and converted to US\$ for ease of international comparison.

This analysis obtained clearance from the Institutional Review Board of the American University of Beirut.

\section{Cost of massive HPV vaccination of all 11-year- old girls.}

The size of the target population of 11-year-old girls was determined from official demographic sources (26). The cost of a national programme using 2 required doses of vaccine was assessed based on the assumption of exclusive use of Cervarix $^{\circledR}$, the vaccine with the lowest retail price on the Lebanese market. The cost estimation did not include the administrative/operational costs of the procedures, as recommended in the WHO cervical cancer prevention and control costing tool (27). These other cost items have not yet been estimated in Lebanon.

\section{Cancer management costs}

The average annual cervical cancer caseload in Lebanon was estimated based on data available from 6 consecutive National Cancer Registry yearly reports (2005-2010)
(17-22). The cost of treating those cases was estimated as a package including diagnosis, in-house and ambulatory treatment. The in-house cost of cancer care varies according to histology and staging. For example, cervical intraepithelial neoplasia cases are often curable on their own, and have not been included in the analysis. For other cervical cancer types, the average cost of care was weighted by 2 levels of invasiveness, as specified in the national treatment guidelines in Lebanon (28). In-house costs of cervical cancer treatment were initially to be obtained from a major private tertiary hospital (American University of Beirut Medical Center) and the largest public hospital in Lebanon (Rafic Hariri University Hospital), to improve the case mix across different payment levels. While the American University of Beirut Medical Center drains more out-of-pocket patients likely to be billed at higher rates, Rafic Hariri University Hospital drains more publicly covered patients likely to be billed at lower rates. The cost of medications were factored into the equation using data available from the public drugs price list available on the Ministry of Public Health website (9). The publicly funded drugs dispensing centres provide cancer drugs free of charge to all citizens requiring chemotherapy.

\section{Plan of analysis}

The cost of a projected national HPV vaccination was calculated and compared with the cost of inpatient and outpatient treatment of cancer cases. The analysis was conducted using several assumptions when adequate data could not be found and is summarized in Table 1. Generally, the assumptions preferred were those in favour of inflating the cost of cancer and thus the benefits of vaccination. A break-even point was projected based on current assumptions.

\section{Results}

\section{HPV vaccination costs}

The population of 11-year-old girls was estimated at 38083 (26). The cost of 2 doses of Cervarix ${ }^{\circledR}$ in Lebanon, at the time of this analysis was US\$142. The implementation of a Cervarix ${ }^{\circledR}$-only vaccination in a given year would therefore cost US\$ 5407790.

\section{Cancer management cost}

The mean annual national caseload of cervical cancer was estimated at 100, accounting for unlikely under-reporting (17-22). Data were obtained from American University of Beirut Medical Center (Table 2), on cases treated between 2010 and 2015, representing about $23 \%$ of the estimated national caseload. For the same period, Rafic Hariri University Hospital indicated that only 3 cases had been treated there. Those cases were considered as particular instances which should not be incorporated in the overall calculations to avoid biasing the results. Consequently, no data from Rafic Hariri University Hospital were used for this analysis. Each hospitalized invasive cancer case treated at the American University of Beirut 


\begin{tabular}{|c|c|}
\hline Vaccine-associated costs & Cancer-associated costs \\
\hline The vaccine provides lifetime protection & $\begin{array}{l}\text { The American University of Beirut Medical Center treats the majority of } \\
\text { the cervical cancer caseload in Lebanon (in fact just } 25 \% \text { ) }\end{array}$ \\
\hline Total coverage of all 11-year-old girls & $\begin{array}{l}\text { Additional outpatient costs (e.g. transportation fees, traditional } \\
\text { treatments and alternative practices) were not included }\end{array}$ \\
\hline $\begin{array}{l}\text { All cervical cancer cases are caused by HPV and can be avoided by } \\
\text { vaccination }\end{array}$ & Indirect costs of cancer were not included \\
\hline $\begin{array}{l}\text { Only the cost of the vaccine will be considered without additional costs } \\
\text { related to personnel and logistics }\end{array}$ & $\begin{array}{l}\text { The additional costs of chemotherapy supplies (solvent, injections, etc.) } \\
\text { were not included }\end{array}$ \\
\hline \multirow[t]{2}{*}{$\begin{array}{l}\text { The cheaper of the } 2 \text { vaccines currently available in Lebanon would be } \\
\text { used }\end{array}$} & $\begin{array}{l}\text { Mortality specific data was not available, nor could it be estimated from } \\
\text { international data }\end{array}$ \\
\hline & $\begin{array}{l}\text { Radiotherapy costs were added for all cancers, even when that therapy } \\
\text { was not indicated }\end{array}$ \\
\hline
\end{tabular}

Medical Center cost US\$ 3916 on average, while a noninvasive case cost US\$2524. The relative proportions of invasive and noninvasive cases were $24 \%$ and $76 \%$ respectively. Based on those relative proportions, the total weighted cost of in-hospital treatment for the mean national load of 100 cases in any given year would be about US\$ 286000 . There was not enough information provided to be able to have a detailed breakdown of cost items, which exclude chemotherapy and radiotherapy obtained as out-patient services (Table 2).

According to the American Cancer Society guidelines followed at the American University of Beirut Medical Center; nonmetastatic cervical cancer cases should receive an average of 28 external beam radiotherapy sessions at US\$ 6500 total cost per case, as well as 5 sessions of brachytherapy (29). The cost of brachytherapy depends on whether the patient underwent a total hysterectomy or not. On average, those 5 sessions of brachytherapy would cost US\$ 5000. Subsequently, receiving radiotherapy would cost a total of US\$11 500 per case. These 2 cost items were added to all cases, notwithstanding the probability for any case to require such therapies or not.

The cost of chemotherapy was also estimated separately as drugs are obtained from a public source and not included in the hospital care bill. Chemotherapy protocols usually vary by cancer invasiveness and body surface area. The average body surface area of women aged 40-59 years was considered as $1.79 \mathrm{~m} 2$, as derived from a national crosssectional survey completed in 2009 (30).

For noninvasive cervical cancer, Ministry of Public Health guidelines call for using $430 \mathrm{mg}$ of cisplatin, 9 vials at US\$10.90 each for a total cost of US\$ 98.1 per case.

For invasive cervical cancer, drugs are either a combination of cisplatin and 5-fluorouracil, or carboplatin and taxol.

- The first combination requires $64440 \mathrm{mg}$ of 5-fluorouracil in 129 vials at US\$2.96 each, for a total cost of US\$382. Cisplatin dosage is $1611 \mathrm{mg}$ from 33 vials at US\$ 10.90 each, for a total of US\$360 per case. Therefore, this combination would cost a total of US\$ 742 per case.
- The second combination requires $4833 \mathrm{mg}$ of carboplatin from 11 vials at US\$ 86.26 each. Hence the cost is US\$ 949. The taxol dosage is $1879.5 \mathrm{mg}$ per case from 19 vials at US\$560.10 each with a total of US\$10 642 . Therefore, this combination would cost a total of US\$ 11591 per case.

The total management cost, in-house and outpatient included, of 1 cervical cancer case in Lebanon in 2017 would therefore range between US\$ 14123 for a noninvasive case and US\$21 582 for an invasive case. Using the weighting ratio of invasive/noninvasive proportions, the total management costs of the assumed annual caseload could therefore be estimated at about US\$ 1591 336. This does not take into account the most recent guidelines of the American Cancer Society calling for the use of more advanced, targeted therapies, which have started to be used but were not yet included as standard care in Lebanon at the time of this analysis (29).

\section{What would it take for the HPV vaccination campaigns to become cost-beneficial?}

The ratio of the expected cost of vaccinating one incoming class of 11-year old girls (US\$ 5407 790) to the expected cost of managing all incident cervical cancer cases (US\$ 1591 336) in a given year is about 3.4/1. To reach a break-even ratio, the price of the vaccine would have to decrease to US\$20.88 per dose, compared to the current price of US\$ 71.00. Conversely, the cost of cervical cancer management would have to increase by $240 \%$. A recent analysis of the cost of oncology drugs covered by the Ministry of Public Health has reported a "compound annual growth rate of 15.6\% between 2008 and 2013" (31). This means that the break-even point, assuming constant rates, may be reached within about 10 years.

\section{Discussion}

This paper is a first attempt in an Arab country to compare the monetary value of mass adoption of HPV vaccination to that of cervical cancer treatment. Using limited available data, the cost-benefit analysis ratio was estimated at $3.4 / 1$ against vaccination. The benefit of mass HPV vac- 
Table 2 Estimation of hospital management costs for cervical cancer cases in Lebanon (data from the American University of Beirut Medical Center, 2010-2015)

\begin{tabular}{llr} 
Item & Value & 113 \\
Cases (cumulative) & 23 \\
Mean annual case load & $53.4(11.1)$ \\
Mean (standard deviation) age (years) & $28-82$ \\
Age range (years) & 24 \\
Proportion of invasive cancer cases (\%) & 3916 \\
Mean in-house treatment cost per invasive case (US\$) & 76 \\
Proportion of noninvasive cancer cases (\%) & 524 \\
Mean in-house treatment cost per noninvasive case (US\$) & 2858 \\
Weighted national estimation of annual cost of in-hospital care (US\$) & 286 o00 \\
\hline
\end{tabular}

Weighted national estimation of the annual cost of care of all cases in Lebanon = US\$1 1591336

${ }^{a}$ Assuming a national annual caseload of 100 , of which $24 \%$ are invasive cases, excluding cost of chemo- and radio-therapies.

cination differs between countries, and even within the same country. For instance, in Thailand, Praditsitthikorn et al. found that screening is a more cost-effective strategy than vaccination, while Termrungruanglert et al. contradicted this a year later $(25,32)$. Mostly, countries with a high incidence of cervical cancer will find that HPV vaccination is cost-effective (33).

Previously, Kim et al. conducted a virtual projection in the extended Middle East and North Africa region using national gross domestic products to find the costeffectiveness threshold in each country. In Lebanon, the cost of a 3-dose vaccine should not exceed US\$ 50 per girl to render vaccination more effective than screening (34). Using our "real" figures, the cost threshold for a 2-dose vaccine would have to be $\leq$ US\$ 41.76 .

A reversal in the direction of this cost-benefit analysis would require either a drastic decrease in vaccines prices and/or an increase in cervical cancer incidence and management costs.

- HPV vaccines are currently monopolized by 2 companies which control the retail pricing until the end of their 20-year patent period, expected around 2025 (35). At that time, the retail price of the cheapest vaccines will have to fall by $70 \%$ to reach a break-even point. Such a major decrease may never be attained. While several low-income countries have obtained large subsidies for vaccine costs under Gavi, the Vaccine Alliance (36), Lebanon is not eligible for such support, and therefore no easing of the potential financial burden of HPV vaccination could be expected from that side.

- The incidence of cervical cancer cases is expected to remain at a relatively low level, if not to decrease, due to the extremely low prevalence of HPV infection in the Lebanese population (4). The projected caseload for 2018 will not surpass 107 cases, practically the same mean number of cases on which this analysis is built (37).
- It may be argued that, despite a small cervical cancer case load, the management cost may mushroom as a consequence of the introduction of newer, more expensive drugs (31). However, most of the increase would affect the more invasive form of cervical cancer, currently believed to be about a quarter of the incident cases. The effect of this increase has already been estimated at an annual growth rate of $15.6 \%$ (31), yet there are already indications of higher inflation rates after 2013. Based on new protocols used at the American University of Beirut Medical Center but not yet incorporated into the national guidelines, cervical cancer management costs may have already inflated by $25 \%$ to reach about US\$2 000000 . Accordingly, the break-even point may occur much sooner, but meanwhile no change in the direction of the cost-benefit analysis findings calculated in 2017 should occur before 2020 .

Not all possible financial consequences of cervical cancer, for example indirect costs shouldered by patients, their families/care-takers and society, could be estimated, nor are they included in this analysis. This limitation is of little importance since this cost-benefit analysis focuses on costs incurred by the National Treasury rather than on those incurred by individuals. Similarly, the cost of lives lost to cervical cancer was not factored in. Unfortunately, disentangled cancer-specific mortality data do not currently exist in Lebanon to allow such a consideration, and the health care and social settings in Lebanon do not allow for the use of mortality rates derived from other countries in the region. Nevertheless, we believe that limited evidence is better than no evidence where public health decisions are concerned. This study will provide the decision-makers with relatively solid arguments to resist the efforts of various lobbies constantly calling for the inclusion of HPV in the national Extended Programme on Immunization. Such an inclusion will automatically mean that the government will have to provide the vaccination free of charge to the entire target population. Our pioneering analysis may inspire a simi- 
lar process in several countries in the Middle East where the issue of HPV vaccination is currently debated.

\section{Conclusions and practical implications}

To run a "classical" cost-benefit analysis, gaps in our health information system would need to be closed, in particular, with regard to the current dynamics of HPV infection in Lebanon, the specific mortality rate for cervical cancer and the staging at diagnosis. Our analysis strongly suggests that massive HPV vaccination is not yet cost-beneficial, and will remain so for several years.
This conclusion may have to be re-assessed by 2020 to account for changes in various elements of the analysis. Meanwhile, vaccines will continue to be available on the market for voluntary use. At the national level, awareness of the importance of obtaining regular Pap smear tests for US\$ 10 in primary health care centres should be increased as appropriate as a feasible and less expensive alternative for cervical cancer prevention and early control.

Funding: None.

Competing interests: None declared.

\section{Analyse coûts-avantages d'un programme national de vaccination contre le papillomavirus humain s'appuyant sur des projections au Liban \\ Résumé}

Contexte : L'adoption d'un programme de vaccination contre le papillomavirus humain (HPV) en population générale fait l'objet de débats au Liban pour des raisons épidémiologiques, socioculturelles, logistiques et économiques.

Objectif : La présente analyse coûts-avantages contribue à la production des données quantitatives nécessaires à la prise de décision concernant les coûts grâce aux données disponibles localement.

Méthodes: Les deux côtés de l'équation de l'analyse coûts-avantages sont l'estimation du coût des campagnes de vaccination contre le VPH ciblant les filles de 11 ans, en recourant au vaccin le moins cher en 2016, et l'estimation du coût de la prise en charge pour le traitement d'un nombre annuel moyen de cas de cancer du col de l'utérus.

Résultats : Une campagne utilisant le Cervarix ${ }^{\circledR}$ seulement coûterait USD 5407790 pour vacciner 38083 filles âgées de 11 ans. Le coût estimé de la prise en charge d'un nombre moyen annuel de 100 cas de cancer du col de l'utérus plus ou moins avancés serait de USD 1591 336. Le seuil de rentabilité le plus proche peut survenir cinq ans après la présente analyse.

Conclusion : La présente analyse coûts-avantages fondée sur des données disponibles limitées montre que la vaccination massive contre le VPH ne serait pas rentable dans les circonstances prévalant en 2016. Néanmoins, certaines indications laissent penser qu'une réévaluation serait nécessaire à l'horizon 2020. Cette conclusion permettra de guider les décideurs de santé publique au Liban et dans d'autres pays voisins de même type.

$$
\text { تحليل تكاليف وفو ائد برنامج وطني متوقع للتطعيم ضد فيروس الورم الحليمي البشري في لبنان }
$$

الخلفية: يدور في لبنان جدل بشأن اعتماد برنامج لتطعيم السكان ضد فيروس الورم الحليمي البشري، وذلك لأسباب وبائية واجتماعية ثقافية ولوجستية واقتصادية. الأهداف: يُسهم هذا التحليل للتكاليف و الفو ائد في إيجاد الأدلة الكمية اللازمة لاتخاذ قرار بشأن التكاليف من خلال بيانات متاحة محلياً.

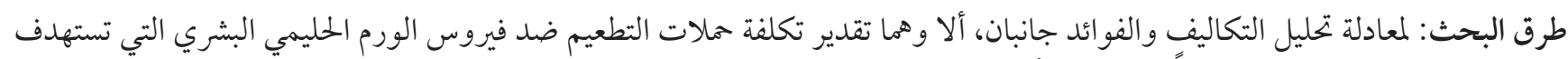

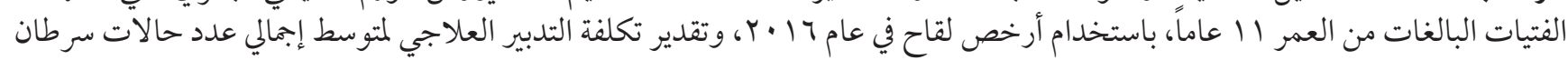
عنق الرحم في السنة.

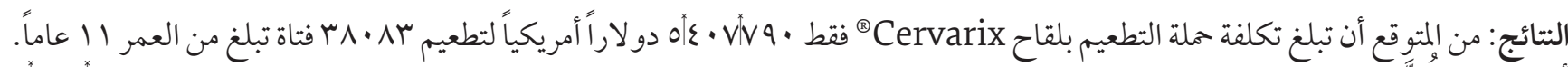

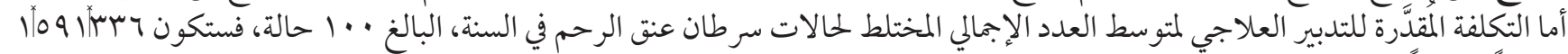

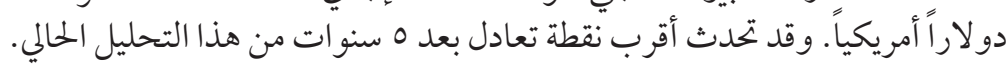

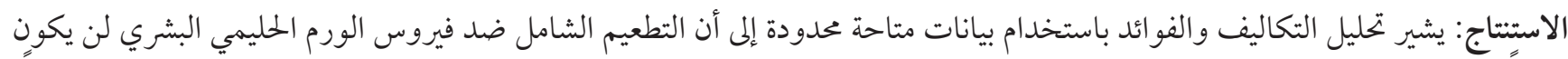

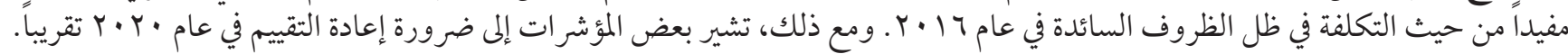

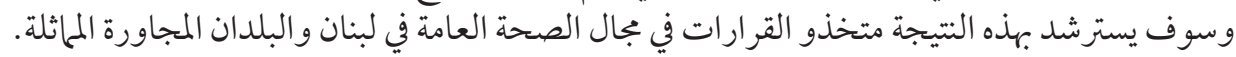




\section{References}

1. Woodman CB, Collins SI, Young LS. The natural history of cervical HPV infection: unresolved issues. Nat Rev Cancer. 2007;7(1):11-22. PMID:17186016

2. Human papillomavirus (HPV) and cervical cancer. Geneva: World Health Organization; 2016 (http://www.who.int/mediacentre/ factsheets/fs380/en/, accessed 30 March 2019).

3. Seoud M. Burden of human papillomavirus-related cervical disease in the extended middle East and north Africa-a comprehensive literature review. J Low Genit Tract Dis. 2012;16(2):106-20. PMID:22371041; doi:10.1097/LGT.obo13e31823a0108

4. Mroueh A, Seoud M, Kaspar H, Zalloua P. Prevalence of genital human papillomavirus among Lebanese women. Eur J Gynaecol Oncol. 2001;23(5):429-32. PMID:12440818

5. Lorenzi AT, Syrjänen KJ, Longatto-Filho A. Human papillomavirus (HPV) screening and cervical cancer burden. A Brazilian perspective. Virol J. 2015;12(1):1. PMID:26208521

6. Finan RR, Irani-Hakime N, Tamim H, Almawi WY. Validity of vaginal testing in detecting human papillomavirus (HPV) genotypes. J Clin Virol. 2000;19(3):163-8. PMID:11090752

7. Finan RR, Irani-Hakime N, Tamim H, Sharide HE, Daccache JL, Almawi WY. Detection of human papillomavirus (HPV) genotypes in cervico-vaginal scrapes of women with normal and abnormal cytology. Clin Microbiol Infect. 2001;7(12):688-92. PMID:11843911

8. Nour NM. Cervical cancer: a preventable death. Rev Obstet Gynecol. 2009;2(4):240. PMID:20111660

9. Lebanon national drugs database. Beirut: Ministry of Public Health; 2017 (http://www.moph.gov.lb/en/Drugs/index/3/4848/lebanon-national-drug-index-lndi-, accessed 30 March 2019).

10. Paavonen J, Naud P, Salmeron J, Wheeler C, Chow S, Apter D, et al. Efficacy of human papillomavirus (HPV)-16/18 ASo4-adjuvanted vaccine against cervical infection and precancer caused by oncogenic HPV types (PATRICIA): final analysis of a double-blind, randomised study in young women. Lancet. 2009;374(9686):301-14. PMID:19586656

11. Harper DM, Franco EL, Wheeler CM, Moscicki A-B, Romanowski B, Roteli-Martins CM, et al. Sustained efficacy up to 4. 5 years of a bivalent L1 virus-like particle vaccine against human papillomavirus types 16 and 18: follow-up from a randomised control trial. Lancet. 2006;367(9518):1247-55. doi:10.1016/So140-6736(06)68439-0

12. Future II Study Group. Quadrivalent vaccine against human papillomavirus to prevent high-grade cervical lesions. N Engl J Med. 2007;2007(356):1915-27. PMID:17494925

13. Markowitz LE, Hariri S, Lin C, Dunne EF, Steinau M, McQuillan G, et al. Reduction in human papillomavirus (HPV) prevalence among young women following HPV vaccine introduction in the United States, National Health and Nutrition Examination Surveys, 2003-2010. J Infect Dis. 2013;208(3):385-93. doi:10.1093/infdis/jit192

14. Van de Velde N, Boily M-C, Drolet M, Franco EL, Mayrand M-H, Kliewer EV, et al. Population-level impact of the bivalent, quadrivalent, and nonavalent human papillomavirus vaccines: a model-based analysis. J Natl Cancer Inst. 2012;104(22):1712-23. doi:10.1093/jnci/djs395

15. HPV vaccine questions \& answers. Atlanta: Centers for Disease Control and Prevention; 2015 (http://www.cdc.gov/vaccines/vpdvac/hpv/vac-faqs.htm, accessed 20 December 2016).

16. Abou-Daoud KT. Morbidity from cancer in Lebanon. Cancer. 1966;19(9):1293-300. PMID:5919063

17. National cancer registry 2010. Beirut: Ministry of Public Health; 2010 (https://www.moph.gov.lb/userfiles/files/Esu_data/Esu_ ncr/BF2010.HTM, accessed 30 March 2019).

18. National cancer registry 2005. Beirut: Ministry of Public Health; 2005 (https://www.moph.gov.lb/userfiles/files/Esu_data/Esu_ ncr/BF2005.HTM, accessed 30 December 2016).

19. National cancer registry 2006. Beirut: Ministry of Public Health; 2006 (https://www.moph.gov.lb/userfiles/files/Esu_data/Esu_ ncr/BF2006.HTM, accessed 30 March 2019).

20. National cancer registry 2007. Beirut: Ministry of Public Health; 2007 (https://www.moph.gov.lb/userfiles/files/Esu_data/Esu_ ncr/BF2007.HTM, accessed 30 March 2019).

21. National cancer registry 2008. Beirut: Ministry of Public Health; 2008 (https://www.moph.gov.lb/userfiles/files/Esu_data/Esu_ ncr/BF2008.HTM, accessed 30 December 2016).

22. National cancer registry 2009. Beirut: Ministry of Public Health; 2009 (http://www.moph.gov.lb/userfiles/files/Esu_data/Esu_ ncr/BF2009.HTM, accessed 30 March 2019).

23. Jit M, Choi YH, Edmunds WJ. Economic evaluation of human papillomavirus vaccination in the United Kingdom. BMJ. 2008;337:a769. doi: 10.1136/bmj.a769; PMID:18640957

24. Mennini F, Rossi PG, Palazzo F, Largeron N. Health and economic impact associated with a quadrivalent HPV vaccine in Italy. Gynecol Oncol. 2009;112(2):370-6. doi:10.1016/j.ygyno.2008.09.031

25. Termrungruanglert W, Havanond P, Khemapech N, Lertmaharit S, Pongpanich S, Khorprasert C, et al. Cost and effectiveness evaluation of prophylactic HPV vaccine in developing countries. Value Health. 2012;15(1):S29-S34. doi:10.1016/j.jval.2011.11.007

26. Statistical bulletin. Beirut: Ministry of Public Health; 2014. 
27. WHO cervical cancer prevention and control costing tool $\left(\mathrm{C}_{4} \mathrm{P}\right)$ user guide: demonstration project version 2.0. Geneva: World Health Organization; 2015.

28. National cancer treatment guidelines. Lebanon: Ministry of Public Health, UNDP; 2012.

29. Treating cervical cancer. Atlanta, Georgia: American Cancer Society; 2016 (https://www.cancer.org/cancer/cervical-cancer/treating.html, accessed 7 April 2019).

30. Nasreddine L, Naja F, Chamieh MC, Adra N, Sibai A-M, Hwalla N: Trends in overweight and obesity in Lebanon: evidence from two national cross-sectional surveys (1997 and 2009). BMC Public Health. 2012;12(1):1. doi:10.1186/1471-2458-12-798

31. Elias F, Khuri F, Adib SM, Karam R, Harb H, Awar M, et al. Financial burden of cancer drug treatment in Lebanon. Asian Pacific Journal of Cancer Prevention. 2016;17(7):3173.

32. Praditsitthikorn N, Teerawattananon Y, Tantivess S, Limwattananon S, Riewpaiboon A, Chichareon S, et al. Economic evaluation of policy options for prevention and control of cervical cancer in Thailand. Pharmacoeconomics. 2011;29(9):781-806. doi:10.2165/11586560-000000000-00000

33. Jit M, Brisson M, Portnoy A, Hutubessy R. Cost-effectiveness of female human papillomavirus vaccination in 179 countries: a PRIME modelling study. Lancet Glob Health. 2014;2(7):e406-e14. doi:10.1016/S2214-109X(14)70237-2

34. Kim JJ, Sharma M, O'Shea M, Sweet S, Diaz M, Sancho-Garnier H, et al. Model-based impact and cost-effectiveness of cervical cancer prevention in the Extended Middle East and North Africa (EMENA). Vaccine. 2013;31(Suppl. 6):G65-77. doi:10.1016/j. vaccine.2012.06.096.

35. Frequently asked questions on patents and exclusivity. Silver Springs, Maryland: US Food and Drug Administration; 2016 (https://www.fda.gov/Drugs/DevelopmentApprovalProcess/ucmo79031.htm\#Howlongisexclusivitygrantedfor, accessed 30 March 2019).

36. Countries eligible for support. Geneva: Gavi, The Vaccine Alliance; 2016 (http://www.gavi.org/support/apply/countries-eligible-for-support/, accessed 7 April 2019).

37. Shamseddine A, Saleh A, Charafeddine M, Seoud M, Mukherji D, Temraz S, et al. Cancer trends in Lebanon: a review of incidence rates for the period of 2003-2008 and projections until 2018. Popul Health Metr. 2014;12(4). PMID:24593777 